Grzegorz Moroz

10.15290/cr.2017.18.3.01

University of Białystok

\title{
Brave New World, \\ Intertextuality and \\ Mieczysław Smolarski
}

\begin{abstract}
In 1948, Polish science-fiction writer Mieczysław Smolarski wrote an open letter to Aldous Huxley in which he accused Huxley of plagiarising, in his famous novel Brave New World (1932), two novels which Smolarski himself had written in the 1920s: Miasto świattości (A City of Light) and Podróż poślubna pana Hamiltona (Mr. Hamilton's Honeymoon). The key argument presented in this paper is that even if Huxley had read these two novels (which is very unlikely), Brave New World would not have been altered in any considerable way, and that in 1931, the year in which he wrote Brave New World, Huxley was already a distinguished novelist and a profound thinker capable of writing a masterpiece without resorting to plagiarism.
\end{abstract}

Key words: Huxley, Smolarski, plagiarism, Brave New World, science fiction, dystopia, intertextuality.

In this paper I will approach the issue of plagiarism, of which Aldous Huxley was accused by a Polish writer, Mieczysław Smolarski, in 1948. The strategy of those Polish scholars who felt that Huxley was (or at least may have been) not guilty of plagiarism ${ }^{1}$ was to point out the limited number of conceptual and ideological schemata in operation within Polish, British and world science fiction and catastrophic literature in the first four decades of the $20^{\text {th }}$ century. Even Antoni Smuszkiewicz, who abstained from pronouncing Huxley not guilty of plagiarism, felt obliged to admit that: "Visions of the world dominated by technology, causes of cosmic catastrophes, applications of extraordinary inventions (rockets, killing rays, etc.) and the motive of an escape from a planet on the verge of destruction point to so limited a number of motives that one really is under the impression that all these different novels were created by one author" (Smuszkiewicz 1982: 204, my translation). However, as I consider myself an Aldous Huxley scholar, not a science fiction scholar, I would like to construct my defence of Huxley using a different strategy. I would like to show that the erudition of Huxley, the range and depth of his reading, made Brave New World a truly intertextual novel, and that the dystopian ideas crucial in the construction of the World State and the

1 Two Polish critics who disagreed with Smolarski were: T. Grzebieniowski "Smolarski versus Huxley", Odrodzenie, 1948, 13-14, 16, and M. Karnasowa, "Mieczysław Smolarski”, Życie i Myśl, 1967, 2, p. 144. 
New Mexico Indian reserve central to Brave New World are to be found not in Smolarski's novels, but in Huxley's own experiences and in the numerous books and essays Huxley had read, many of which became more or less obvious intertexts in Brave New World. And that even if Huxley had miraculously and surreptitiously learnt Polish and read Smolarski's novels, Brave New World would not have been altered to any considerable degree. I will also attempt to show in the second part of this paper that Huxley's erudition, intellect and concern for the future of the world led to him write both works of non-fiction and fiction (Brave New World Revisited and Island, respectively) which developed ideas he introduced first in his novel from the early 1930s.

In 1948, sixteen years after the publication of Brave New World, Mieczysław Smolarski, the author of a few science fiction novels and short stories written in the 1920s, wrote a newspaper article in the Polish literary magazine "Nowiny Literackie" ["Literary News"]. The article had the form of an open letter, entitled "List do Aldousa Huxleya" ["A Letter to Aldous Huxley"]. Smolarski started his letter with self-promotion, listing novels he had written, and translators who had approached him to have his books translated. Yet the only book of his that he presents as actually having been translated into a foreign language is a historical novel for young readers about the Polish king Władysław Warneńczyk. Smolarski reports that during WWII he was approached by an acquaintance of his who had told him that he had read this novel in Bulgarian. For Smolarski this is clear proof that because of "the loose morality pervading the international book market" there exist numerous translators "who want to avoid paying royalties" (Smolarski 1948: 7, my translation). Smolarski immediately moves to report another conversation with another acquaintance of his that he had during WWII. This unnamed acquaintance asked him: "Please, tell me this: have you robbed Huxley or has Huxley, in Brave New World, robbed you?" (Smolarski 1948: 7 , my translation). Smolarski now shows that he is indignant; he takes it for granted that some 'robbery' must have been committed, and because he had written both Miasto świattości (A City of Light) and Podróż poślubna pana Hamiltona (Mr. Hamilton's Honeymoon) earlier than Huxley's Brave New World, it is obvious to him that Huxley had committed this hideous crime and should pay compensation. ${ }^{2}$

The main part of Smolarski's letter consists of attempts to show that the similarities between his two novels and Brave New World are not accidental, and that his Mr. Hamilton's Honeymoon contains a serious "philosophical idea" which is as unique and novel as the ideas which are associated with such key novels as Swift's Gulliver's Travels, Francis Bacon's New Atlantis and H.G. Wells's

\footnotetext{
2 One may really wonder at this point why Smolarski waited for fifteen years to bring up his charges against Huxley. The Polish translation of Brave New World by Stanisława Kuszelewska was published by Rój in 1933, just a year after the original version had been published, and it is hardly imaginable that Smolarski, a writer and a critic, learnt about it only in 1940 from a conversation with an unidentified friend. Smolarski's letter, I think, may be read in the context of the ideological cold war that was being waged in post-war, communist Poland. Smolarski's accusation that Huxley may have stolen Smolarski's ideas through a co-worker of his "scavenging on Slavonic literatures” (“żerujących na literaturach słowiańskich”) (Smolarski 1948: 7) supports this perspective.
} 
The War of the Worlds. And that it is this unique idea of the World State, with its stability, happiness through uniformity, but also some brewing dissent, which Huxley "robbed" Smolarski of. Smolarski adds some more similarities which supposedly proves Huxley guilty of theft. He states: "In my novel Hamilton is the supervisor of a huge block of flats of 50 floors and 20000 inhabitants; in Huxley's book we find 60 floors, 36 floors (sic!) and 7000 rooms, etc." (Smolarski 1948: 7, my translation). Smolarski compares the love affair between his "savage" Andrzej and Maja with Huxley's John the Savage and Lenina Crowne. He points out the fact that at one moment both Andrzej and John become disenchanted with "cities of light". Smolarski writes about the "electric wall" which divides civilization from barbarity in both novels as other proofs of the "robbery".

Yes, it is true that in Brave New World there is the World State with evident stability, but also moral and intellectual shallowness and discontent, and that in A City of Light Smolarski had displayed similar features a few years earlier, and that there also exists the World State in Smolarski's Mr. Hamilton's Honeymoon. But as science fiction literature historians tell us, the concept of the World State had been used by writers before Smolarski and Huxley, from Louis-Sébastian Mercier L'An 2400 [Year 2440] published in 1772, to Yevgeny Zamiatin's We (1924). For example, in H.G. Wells's The Time Machine (1895) we have the fundamental dichotomy between the civilized, effeminate and promiscuous Eloi and the barbarian, savage Morlocks, a dichotomy which appears as central, albeit in altered forms, both in A City of Light and in Brave New World.

Smolarski is not by any means the only writer whose megalomania and greed has carried him away to the borders of the ludicrous; for it is ludicrous indeed, at least in my opinion, to compare the uniqueness of his Mr. Hamilton's Honeymoon with Gulliver's Travels, The War of the Worlds or New Atlantis, and to claim to have coined the phrase "darkness visible". His weird, and, in my opinion, unfounded accusations still resonate, to some considerable degree, thanks to the Polish literary critic Antoni Smuszkiewicz. Smuszkiewicz's Zaczarowana Gra: Zarys Dziejów Polskiej Fantastyki Naukowej [The Enchanted Game: An Outline History of Polish Science-Fiction Literature] (1982) dealt with the issue of Smolarski's accusations of Huxley's Brave New World being a plagiarism of Miasto Światłości and Podróż poślubna pana Hamiltona. In chapter IX of his book, entitled "Katastroficzne wizje przyszłości" ["Catastrophic Visions of the Future”], Smuszkiewicz summarized and briefly analysed these two novels by Smolarski, and then he noted:

The same philosophical ideas, the same basic content, and even the same system of social organizations could, a few years later, be found in the famous novel by Aldous Huxley, Brave New World (1932), which became a great success and is still considered as a teasing answer to the utopian visions of the world in the future popular in the West at the beginning of the 20th century. The opening chapters of Brave New World very closely resemble Mr. Hamilton's Honeymoon, while the following chapters-starting from Chapter VI of Huxley's novel- resemble A City of Light. Do we have here an unbelievable similarity of concepts, or is it a case of crude plagiarism committed on the novels of our writer? It is difficult to establish without undertaking scrupulous research, which could become an object of a separate study. (Smuszkiewicz 1982: 202, my translation). 
Later on, Smuszkiewicz added that Smolarski's letter was delivered to Huxley, "who preferred not to answer it, although he, as a respected writer, was bound to do so" (Smuszkiewicz 1982: 203, my translation). Three years later, in 1985, Smuszkiewicz wrote an Afterword to the new edition of A City of Light (which was published in 1988). He still refrained from the final verdict of plagiarism, but insisted that: "regardless of whose side of the story literary history will belatedly take, one thing is certain: this anti-utopian concept based on lack of conviction in civilizational progress, and the critical attitude to the development of social mechanisms first appeared in the works of Mieczysław Smolarski (Smuszkiewicz 1988: 244, my translation).

Why did Smuszkiewicz not re-read Brave New World, and why did he not decide for himself if Huxley had plagiarized Smolarski's novel? Why did he leave it for some mysterious "history of literature" to make its (belated) pronouncement in some more or less distant future? Perhaps it was because Huxley's novel was banned in Poland in the pre-1989 era of communism, and we are faced with a classic case of self-censorship. Of Smuszkiewicz being constrained by the political climate of that time. Perhaps he felt that the summary of Brave New World and its comparison with Smolarski's novel would be cut out by censors.

When I read Smolarski's accusations I became very curious about the content of his two novels. I got hold of them, read them, then re-read Brave New World. It turned out that I had embarked on an interesting journey through literary traditions in Anglophone and Polish science fiction in the first three decades of the $20^{\text {th }}$ century. After a close reading of these three novels I would like to argue that the similarities between Smolarski's novels and Brave New World, which he enumerated in his "Letter to Aldous Huxley", should not be considered in the light of being accidental (or not), but, rather, in the light of being superficial. The background, and the ways in which two different communities, of the World State and the New Mexico reserve, are constructed in Brave New World could be explained clearly and fully without referring to Smolarski at all.

In the spring and summer of 1931, when Huxley was writing Brave New World in his house in Sanary-sur-mer on the French Riviera, he was 37 and he had written four novels, two books of poetry and numerous essays. The first two volumes of the collected essays of Aldous Huxley, edited by Robert Baker and James Sexton, cover the years 1922-1929; they contain almost a hundred essays and run to more than one thousand pages of essays Huxley wrote in that period. These essays are divided by the editors into four sections: I. Architecture, Painting, Music, Literature, II: History, Politics, Social Criticism, III: Science, Philosophy, Religion, IV. Travel. The range, scope and depth of these essays best illustrate the point that Huxley was one of the best predisposed men to write a poignant dystopian prophecy. In a letter to a friend, Mrs. Kathevan Roberts, dated 18 May 1931, Huxley wrote:

I am writing a novel about the future [Brave New World] —on the horror of Wellsian Utopia and a revolt against it. Very difficult. I have hardly enough imagination to deal with such a subject. But it is none the less interesting work. (Huxley 1969: 348) 
So, one of the key inter-textual sources for the book is unravelled here: the utopian but also dystopian science fiction of H.G. Wells. One may as well add here the long English/British tradition of utopian literature, from Thomas More's Utopia (1516) to William Morris's News from Nowhere (1890); the tradition was very well known to Huxley, who had, after all, studied English Literature at Oxford. There are many other intertexts in Brave New World, from William Shakespeare and John Milton, but also from writers contemporary with Huxley, like a friend of his, T.S. Eliot. Before I move on to deal with the issue of the intertextual elements used to construct two distinct communities in Brave New World, I will try to offer some alternative intertextual sources to the ones which Smolarski suggested in his "Letter to Aldous Huxley".

In his letter Smolarski accused Huxley of "stealing" the notion of "darkness visible" from him. It is true that Huxley did not invent this phrase; he simply took it from a writer whom he knew probably rather better than Smolarski knew him, namely from John Milton, who, in Paradise Lost (1667), in his description of hell, wrote: "yet, from those flames no light, but darkness visible" (1.62f).

Smolarski accuses Huxley of "stealing" the idea of old books being the source of wisdom, which is forgotten in the World State. And he recalls that in his A City of Light the monk found some books from which he taught ancient wisdom to Andrzej, whereas John the Savage found a copy of Shakespeare to teach himself. In Smolarski's novel we learn very little about the contents of these books, but we might tentatively assume that they are theological treatises on Christianity, or books which told Andrzej that he lived in a place that used to be called Poland (Smolarski 1988: 10). On the other hand, the role of Shakespeare, his language and his mindset, is absolutely fundamental to the whole understanding of Huxley's novel. Shakespeare's poetry in Brave New World represents both humanism and the ultimate beauty of the English language, the only two values which Huxley could muster in 1931 against the soma-induced happiness in the World State on the one hand, and the despair of John the Savage, leading to his suicide. There are more than fifty direct quotations and paraphrases from Shakespearean plays and poems in Brave New World. (On the intricate play of these quotes and paraphrases, see, for example, www.shmoop.com > Literature > Brave New World > Analysis). While illustrating differences in Smolarski's and Huxley's treatment of love themes I will comment on Huxley's textual appropriation of two phrases from Shakespeare: "Impudent strumpet!" and “O brave new world![...]"

It seems worthwhile, while dealing with the issues of intertextuality, influences and similarities in Huxley's and Smolarski's novels, to compare how differently the love affairs of the paired lovers (John the Savage and Lenina Crowne, Andrzej and Maja) are represented. In Smolarski's A City of Light the lovers make a narrow escape in a space rocket, a typical popular fiction happy ending. In Huxley's novel, the differences between the sexual life-styles of the World State and the reserve (sexual promiscuity in the former and the predominance of the model of 'sexual fidelity' in the latter) are constructed in such a way that they create serious repercussions for plot development. When John realizes that the woman he is love with, Lenina Crowne, has casual sex with other partners (a habit encouraged by the World State and therefore in her view harmless) 
he falls into a rage and attacks her with the very words Othello used before killing Desdemona: “Impudent strumpet!" (Othello, Act 4, scene 2, Huxley 1984: 175). A 'strumpet” was Shakespeare's archaic word for a 'whore'. It is not a case of Huxley's 'plagiarism' performed on the 'holy texts of the Bard of Stratford', but a part of the complex network of the intertextual play of words and ideas. The guilt of these two women is not real; it is created in the heads of the jealous lovers. Desdemona was framed by Iago, and she was not unfaithful, whereas Lenina's 'infidelity' was merely part of John's mindset, of his desire, and his inability to think in terms of inter-cultural difference. In Huxley's novel Lenina's sexual behaviour is presented as one of a few key events which mark the growing disillusionment of John with the World State as 'the brave new world'. And we have the whole spectrum of John's emotions with which he repeats the words of Miranda, "How beauteous mankind is! O brave new world that has such people in it" (The Tempest, Act 5, scene 1), from original wonder and fascination, through disillusionment and rejection of it, to final despair and suicide.

The textual construction of both social organizations - the World State and the Indian community living on the reserve-created by Huxley in Brave New World can be easily accounted for without referring to Smolarski's two novels. As far as the World State is concerned, there is little doubt that its origins should be found not so much in the future, but in the present, in the rise of the Soviet Union and the formation of the League of Nations in response to the Great War. During his round the world trip of 1925-1926 the Huxleys arrived in San Francisco in the spring of 1926. They stayed in California for a few weeks and then on the way to New York they spent a few days in New Mexico and became acquainted with the pueblo Indian culture there (Higdon 2008: 137). Huxley's travel book Jesting Pilate was published in the same year. In Jesting Pilate, from the moment Huxley describes their landing in California and then travelling through it, the narration, earlier detached, aloof and essayistic, changes into a syncopated frenzy:

Jazz it up, jazz it up. Keep moving. Step on the gas. Say it with dancing. The Charleston, the Baptists, Radios and Revivals. Uplift and Gilda Gray. The pipe organ, the nigger with the saxophone, the Giant Marimba-phone. Hymns and the movies and Irving Berlin. Petting Parties and the First Free United Episcopal Church. Jazz it up! "N.C. Beskin, the CONVERTED JEW, back from a successful tour, will conduct a tabernacle campaign in Glandale." 'WHY I BECAME A CHRISTIAN?' Dressed in Jewish garb [...] Third Movement. Mother's Day (Mr. Herring of Indiana, "The Father of Mother's Day." But why not Flapper's Day? It would be more representative, more democratic, so to speak. For in Joy City there are many more Flappers-married as well as unmarried-than Mothers [...] Thousands and thousands of flappers, and almost all incredibly pretty. Plumply ravishing, they give, as T.S. Eliot has phrased it, a "promise of pneumatic bliss," ${ }^{3}$ but of not much else, to judge by their faces. So curiously uniform, unindividual, and

3 "promise of pneumatic bliss" comes from T.S. Eliot's poem "Whispers of Immortality" (1920), where the appropriate fragment reads: "Grishkin is nice: her Russian eye/Is underlined for emphasis:/Uncorseted her friendly bust/ Gives promise of pneumatic bliss." 
blank, Hardly more expressive to the foreign eye, at any rate-than any of the other parts of that wellcontoured anatomy which they are at such pains to display. (Huxley 2001b: 551)

The Los Angeles, Joy City, of 1926, with its economic boom, bootlegged cocktails, and promiscuous flappers emanating "pneumatic bliss", could be treated as a starting point for the London of the World State in the year 632 After Ford, as depicted in Brave New World, where its heroine, the promiscuous Lenina Crowne, is described as possessing "pneumatic bliss" a few times, and the Solidarity Service Day with its syncopated rhythm and lyrics "Orgy-porgy, Ford and fun,/Kiss the girls and make them One./Boys at one with girls at peace;/orgy porgy gives release."(Huxley 1984: 84$)^{4}$ may be seen as a combination of weird religious services and the wild jazz age parties described in Jesting Pilate. Obviously, the London of 632 A.F. possesses many features that were not there in the L.A. of 1926. Huxley's extensive interests in science (especially biology) and social sciences had led him to construct a sophisticated, prophetic vision of the dystopian World State. The World State's motto "Community, Identity, Stability" is achieved through social engineering, neo-Pavlovian conditioning, Bakchanovsky's eugenics, Malthusan belts and hypnopaedia (the process of teaching, or to be more precise, 'conditioning' young boys and girls while they sleep). These concepts are witty prophecies on developments in such areas as biology, physiology, demography and psychology. The seriousness of Huxley's purpose to create the world of the future derived from the present developments of sciences (which, after all, is one of the key futures of the s-f genre) can also be detected in two texts which are commentaries on Brave New World, "The Forward", which was written for the 1946 edition of the novel, and, more importantly, Brave New World Revisited (1959). The latter is a collection of scholarly essays taking the World State as presented in Brave New World as a point of departure and tracing developments in such disparate areas as: I. Overpopulation, II. Quantity, Quality, Morality, III. Over-Organization, IV. Propaganda in a Democratic Society, V. Propaganda under a Dictatorship, VI. The Art of Selling, VII. Brainwashing, VIII. Chemical Persuasion, IX. Hypnopaedia, X. Education for Freedom, and XI. What Can Be Done. As we can see from the titles of the chapters (each chapter could be read as an 'independent' essay), after nine of them showing the real and potential dangers in the development of social organization, both in free, democratic countries and in dictatorships (of diverse origins), the two final chapters explore positive, utopian perspectives; a very unusual thing indeed in the 20th century. It should be noted that Huxley is, to the best of my knowledge, the only writer audacious enough to write after a truly dystopian novel (Brave New World) not only non-fiction with an optimistic bias, but also truly utopian fiction. Huxley, as he admitted in the 1946 forward to Brave New World, while writing this novel in the summer of 1931, had not been prepared intellectually to offer a positive, utopian solution, and acknowledged that he was able to construct only

4 This is yet another case of Huxley's intensive intertextual approach. These lyrics are a joyful travesty of the famous, traditional nursery rhyme: "Georgie Porgie, Pudding and pie,/ Kissed the girls and made them cry/ When the boys came out to play,/ Georgie Porgie ran away." 
this horrible alternative "between insanity on the one hand, and lunacy on the other" (Huxley 1984: 6). But after his pacifist and mystical conversion of the late 1930s, the situation altered. First we got the 'perennial-philosopher' John Propter in After Many a Summer Dies the Swan (1939), not only making philosophical comments on the horrible state of mankind at the threshold of the Second World War, but constructing a positive utopia in the shape of a local, Jeffersonian democracy. In Huxley's final novel, Island (1962), the utopia is much more widespread. The island community of Pala is based on a synergically positive mixture of Eastern mysticism with Western rationality, a 'perennial philosophy' shown as a reality in the brief moment of peace and tranquillity before the deadly attack of the imperialist neighbour greedy for Pala's crude oil.

One of the key arguments Smolarski used in his plagiarism letter was that the world of affluence and plenty was separated from the world of barbarity by the electric fence. This is true, but whereas in Smolarski's novel it is the "city of light" which is the exception, and all the world outside it is rank barbarity, in Huxley's novel the situation is more or less opposite. The reserve in New Mexico is the only place outside the World State preserved as a reserve for scientific (specifically eugenic) research. The whole concept of setting the reserve in New Mexico, among the Indians practising Penitente-ism, is owed to a large extent to D.H. Lawrence and the role he played in Huxley's life. Huxley was at first fascinated by Lawrence: his internal dynamism, his 'religion of blood' and his non-conformism in life. Huxley scholars agree that the only person of integrity in Huxley's complex novel Point Counter Point is Mark Rampion, a figure clearly modelled on D.H. Lawrence (see, for example, Firchow 1972: 109). Lawrence was fascinated by New Mexican Indians, their culture and rituals (the Lawrences owned a ranch in Taos, close to an Indian pueblo), and Lawrence described both their culture and rituals in his non-fiction-in the travel book entitled Mornings in Mexico (1927) - as well as in the novel entitled The Plumed Serpent (1926). Jerome Meckier, one of the most renowned Huxley scholars, has quite recently convincingly argued that the character of John the Savage was based on D.H. Lawrence. Meckier stated that: "Lawrence succumbed to tuberculosis in 1930 at the age 44, dying rather pathetically before Aldous's very eyes, virtually in Maria Huxley's arms. Two years later, Huxley caricatured his erstwhile mentor, killing him off in Brave New World as John Savage" (Meckier 2007: 185). And later in his paper Meckier added: "Because Huxley felt that Lawrence had no answer to death, his alter ego in the novel can find no answer either[...] Lawrencian philosophy, the desire for an allegedly simpler, nobler, more vital way of life, has no future; it is no more death-proof than Lawrence was. (Meckier 2007: 187) (See also, Hidgeon 2008, and Moroz 2013).

The conflict between the values of the World State and the values represented by John the Savage is described by Huxley in a detached third person narration and in the 'unmarked' English of the educated elite of the 1930s. But key parts of the novel are written in two very different and very distinguished types of English: the language of propaganda, indoctrination and conditioning, and the powerful, poetic (and poignantly archaic) language of William Shakespeare's plays and poems.

In Chapter III, for example, Huxley introduces an unusual technique, modernist in a sense, when the flow of the narration gets broken and we have shorter and shorter snippets of condition- 
ing slogans interspersed with the thoughts and conversations of the key characters. For example, the slogans to stimulate consumption in the World State are repeated over and over again. Two of them are a playful travesty of slogans in English which were used to stimulate something opposite to consumption: prudence and thrift: "Ending is better than mending, the more stitches the less riches" (Huxley 1984: 54). While Bernard Marx (the World State intellectual) reveals the mechanism of hypnopeadia: "One hundred repetitions three nights a week for four years, thought Bernard Marx, who was a specialist on hypnopaedia. Sixty two thousand four hundred repetitions make one truth. Idiots." (Huxley 1984: 52).

All these features make Brave New World a unique and powerful novel, rightly regarded as one of the most important novels of the twentieth century, a novel whose prophetic powers have not diminished with the passage of decades (see, for example Margaret Atwood's text on the new edition of Brave New World in 2007). Both A City of Light and Mr. Hamilton's Honeymoon are basically adventure stories with prominent romance themes, which happen to be placed in the distant future, which is presented more in terms of some technical gadgets and a catastrophic threat than of a coherent, dystopian vision. They are of interest only to a diligent historian of Polish sciencefiction literature. I am deeply convinced that even if Aldous Huxley had learnt Polish and read Smolarski novels, or even if he had employed 'scouts' to 'scavenge' through Slavonic literature in search of great ideas to steal (these two options are suggested by Smolarski in the closing paragraph of his "Letter to Aldous Huxley"), Brave New World would not be altered in any significant way.

\section{References}

Atwood, Margaret. 2007. Everybody is Happy Now. The Guardian, 17 Nov, www.theguardian.com/ books/2007/nov/17/classics.margaretatwood (21 December 2017).

Firchow, Peter. 1972. Aldous Huxley: Satirist and Novelist. Minneapolis: University of Minnesota Press.

Higdon, David Leon. 2008. Aldous Huxley and the Hopi Snake Dance. Aldous Huxley Annual 8. 137-152.

Huxley, Aldous. 1969. Letters of Aldous Huxley. Grover Smith (ed.). New York: Harper \& Row.

Huxley, Aldous. 1984. Brave New World and Brave New World Revisited. London: Chatto \& Windus, The Hogarth Press.

Huxley, Aldous. 2000a. Complete Essays: Volume I: 1920-1925. Robert S. Baker and James Sexton (eds.). Chicago: Ivan R. Dee.

Huxley, Aldous. 2000b. Complete Essays: Volume II: 1926-1929. Robert S. Baker and James Sexton (eds.). Chicago: Ivan R. Dee.

Meckier, Jerome. 2007. On D.H. Lawrence and Death, Especially Matricide: Sons and Lovers, Brave New World, And Aldous Huxley's Later Novels. Aldous Huxley Annual 7. 185-222.

Moroz, Grzegorz. 2013. Of Death, Grief, John the Savage, Aldous Huxley and D.H. Lawrence. In: Zbigniew Białas, Paweł Jędrzejko and Julia Szołtysek (eds.), Culture and the Rites/Rites of Grief, 183-191. Newcastle-upon-Tyne: Cambridge Scholars Publishing. 
Smolarski, Mieczysław. 1948. List do Aldousa Huxleya [A Letter to Aldous Huxley]. Nowiny Literackie 4. 7.

Smolarski, Mieczysław. 1988. Miasto światłości [A City of Light]. Poznań: Wydawnictwo Poznańskie.

Smuszkiewicz, Antoni. 1982. Zaczarowana gra: Zarys dziejów polskiej fantastyki naukowej [The Enchanted Game: An Outline History of Polish Science-Fiction Literature]. Poznań: Wydawnictwo Poznańskie.

Smuszkiewicz, Antoni. 1988. Posłowie [Afterword]. In: Mieczysław Smolarski, Miasto światłości. Poznań, Wydawnictwo Poznańskie. 